\title{
Techno-Economic Analysis of Solar Absorption Cooling for Commercial Buildings in India
}

\author{
Muthalagappan Narayanan*
}

European Solar Engineering School, Dalarna University, Sweden

\begin{abstract}
Space cooling and heating always tends to be a major part of the primary energy usage. By using fossil fuel electricity for these purposes, the situation becomes even worse. One of the major electricity consumptions in India is air conditioning. There are a lot of different technologies and few researchers have come up with a debate between solar absorption cooling and PV electric cooling. In a previous paper, PV electric cooling was studied and now as a continuation, this paper focuses on solar thermal absorption cooling systems and their application in commercial/office buildings in India. A typical Indian commercial building is taken for the simulation in TRNSYS. Through this simulation, the feasibility and operational strategy of the system is analysed, after which parametric study and economic analysis of the system is done. When compared with the expenses for a traditional air conditioner unit, this solar absorption cooling will take 13.6 years to pay back and will take 15.5 years to payback the price of itself and there after all the extra money are savings or profit. Although the place chosen for this study is one of the typical tropical place in India, this payback might vary with different places, climate and the cooling demand.
\end{abstract}

Keywords: solar cooling, TRNSYS, absorption cooling in India, renewable cooling, solar air conditioning, commercial building cooling

Article History: Received May 12 ${ }^{\text {th }}$ 2017; Received in revised form August 15 ${ }^{\text {th }}$ 2017; Accepted 1st Sept 2017; Available online How to Cite This Article: Narayanan, M. (2017). Techno-Economic Analysis of Solar Absorption Cooling for Commercial Buildings in India. International Journal of Renewable Energy Development, 6(3), 253-262.

https://doi.org/10.14710/ijred.6.3.253-262

\section{Introduction}

Air conditioning (cooling) tends to be the largest part of the energy consumption in Sunbelt regions. According to World Bank, cooling demand accounts to almost half of the primary energy use in tropical climates (The World Bank, 2008). With usage of electricity produced from fossil fuels for this purpose, the situation becomes even worse. The advantage for solar energy to satisfy this demand is that the demand and solar energy availability is almost at the same time over the season, day and time of the day. There are different types of solar cooling options such as solar PV electric cooling, solar mechanical cooling, solar absorption systems, solar adsorption system, solar desiccant cooling and passive solar cooling. But the most economic and feasible way for a tropical city was found out to be solar absorption system or a solar $\mathrm{PV}$ driven $\mathrm{AC}$ powered air conditioner system (Fong et al., 2010).
In India the requirement of cooling is high. The whole summer has cooling demand in residential building and at least eight months of everyday operation is required in commercial buildings. Cooling in India accounts almost $50 \%$ of the total electrical energy consumption (The World Bank, 2008). There are policies which are likely to be implemented that commercial and industrial buildings must produce some of their consumption by their own (TNERC, 2012). The industrial and commercial buildings in most states of India have already attained grid parity (Breyer, 2014).

Since the research initiatives of solar cooling, there is debate over PV and solar thermal application for cooling. The fact is that solar collectors are more efficient than PV, but the whole system has to be built if solar collectors are used while PV Cooling units are readily available. Moreover, the $\mathrm{COP}$ of the $\mathrm{PV}$ electric air conditioners are 3 to 6 , but the collector systems using absorption or desiccant cooling

\footnotetext{
* Corresponding author: muthalagappan.n@gmail.com
} 
technologies now have less than 1.2 (Eicker et al., 2014; Fong et al., 2010; Lazzarin, 2014; Otanicar et al., 2012). In a research in Hong Kong, it was seen that PV electric cooling and solar absorption were among the best efficient technologies of the different types being compared in that study for a building in Hong Kong (Fong et al., 2010).

Many researchers started with solar assisted cooling systems right in the 90's. Initially, the peak COP was around 0.55 (Hammad and Audi, 1992). First of computer coding based simulations were done by Haim et al (1992) with single stage absorption systems. Florides et al (2001) were the first to simulate a solar absorption cooling system with TRNSYS for a building in Cyprus. The idea of building solar absorption systems for office buildings was brought up by Ursula Eicker and Dirk Pietruschka (2009). Soon absorption cooling systems were built up in hot regions like USA (Joel K. Dickinson et al, 2010) and Abu Dhabi (A. Al Alili, 2008). They modelled the system with TRNSYS, optimized the design parameters and went on to build systems. Recently, A Ghafoor and A Munir (2015) showed a thermo-economic analysis for Pakistan showing that solar absorption cooling is also viable in this region and is well profitable than using the grid electricity for cooling. More recently in 2015, VSM solar air conditioning systems ltd. built their first commercial office building solar absorption system at Infosys office building in India (India Today, 2015)

For the building as described below, a PV electric cooling system is designed with PVSYST grid connected system and external battery, as published in (Narayanan 2015). The system was designed such that it satisfies the peak cooling period and the payback time was found out to be 14.5 to 21 years. One of the important things to note is that the battery is designed with no autonomy on peak summer days and the feed-in power to the grid is also taken into account without which the payback is 26 years. One of the main conclusions are that PV cooling is economically and technically viable in India.

In this research work, the focus is on the commercial buildings as they are the most buildings which use cooling in the general working hours say 9 am to $8 \mathrm{pm}$. These buildings could be schools, universities, libraries, office premises, shopping centers, etc. where solar systems will serve as additional asset and brand value. With a small storage, the cooling demand of these buildings will be easy to satisfy. In addition to this, an option to use electricity from the grid for supplying auxiliary heater might be provided, so we have a backup source for overcast days and hence the storage unit can be designed small.

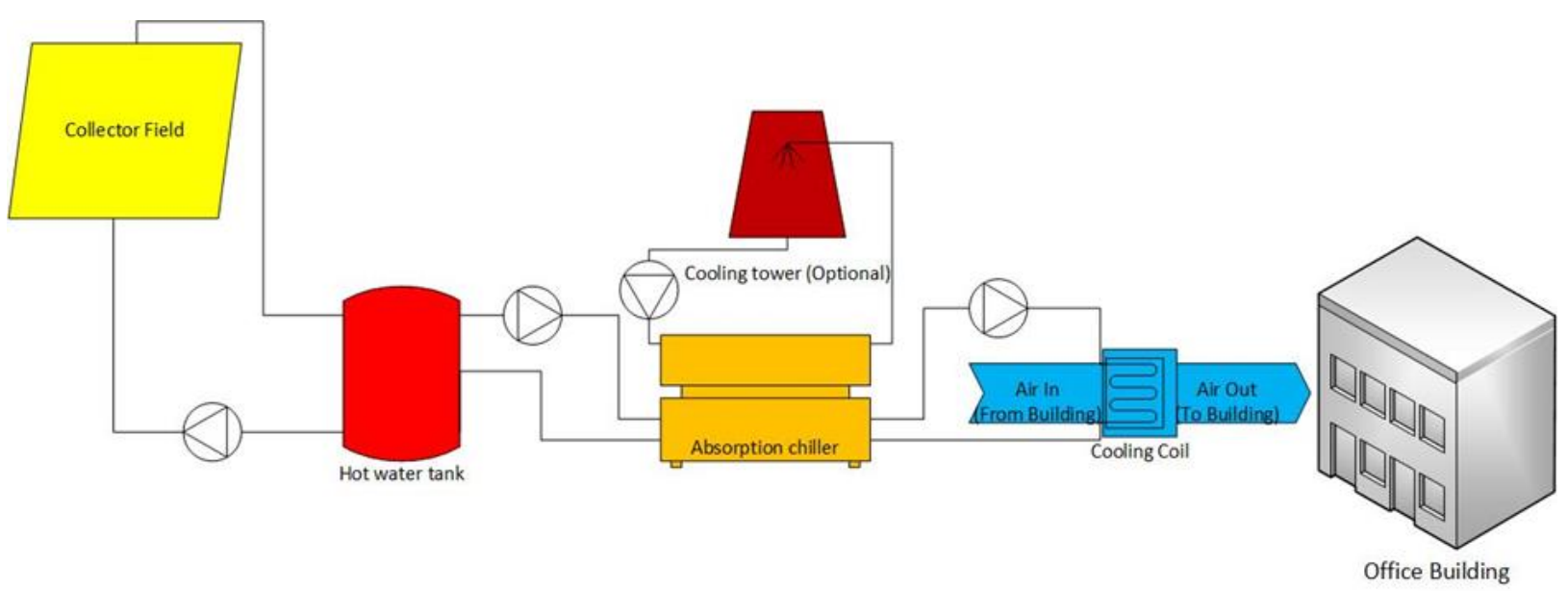

Fig. 1 System layout

\section{System Description}

In an overview (as shown in Fig.1), the system will mainly consist of an evacuated tube collector with a hot water storage unit. The hot water from the unit is supplied to absorption chiller which delivers chilled water to the cooling coil, which in turn delivers cold air to the building. There is a choice between open cooling water loops or with cooling tower connecting the absorption chiller. The desired indoor space temperature in India is around $22^{\circ} \mathrm{C}$ to $27^{\circ} \mathrm{C}$ and for calculations $25^{\circ} \mathrm{C}$ is taken. The idea is to see if it is viable to use solar absorption cooling for such a building both in terms of technical and economical point of view. There are lot of commercial building which have large amount of roof space and for such building owners the investment into solar is not a big issue if it is economically profitable in the long run. The system defined is a commercial building in Chennai, India $\left(13.1^{0} \mathrm{~N}\right)$ with 4 floors which has a roof area of $289 \mathrm{~m}^{2}$ and floor area summing up to $1156 \mathrm{~m}^{2}$. The required volume to be cooled is $3468 \mathrm{~m}^{3}$. The building was assumed to be occupied by 100 persons 
who were working with 100 computers from 9 a.m. to 8 p.m. and the $U$ value and $R$ value of building was calculated to be $2,453 \mathrm{~W} / \mathrm{K}$ and $360,956 \mathrm{~kJ} / \mathrm{K}$. The U value was calculated with typical building structure and their values from the region. The $R$ value was calculated manually with density of wall as 1900 $\mathrm{kg} / \mathrm{m} 3$ and the specific heat as $0.9933 \mathrm{~kJ} / \mathrm{kgK}$.

For the loads mentioned above, a solar absorption cooling system is designed. Since the medium temperature absorption chillers require hot water in the range of $75-95^{\circ} \mathrm{C}$, evacuated tube collectors are selected. A hot water buffer tank is used for storage of hot water to support the chiller operation in the evening office hours and also to deliver a constant temperature to load. The absorption chiller is a single effect $\mathrm{LiBr}$ absorption chiller. A Yazaki absorption chiller is taken as an example for designing the system. Its performance data, size, mass flow and temperature of inlets to the chiller were taken from the datasheet (Yazaki Energy Systems Inc., n.d.,). The optimum size of the chiller is found out to be $105 \mathrm{~kW}$. The chiller is being operated by a combination of time control and an aquastat, where controlling the room temperature to $25^{\circ} \mathrm{C}$ during the office hours is the primary aim.

A normal type 107 absorption chiller is used. The example performance data file is taken from the
TRNSYS data and then edited in accordance with the performance of the Yazaki SC-30 105kW absorption chiller. The COP of such a system given in data sheet is 0.8 , which is input in the chiller parameter. The hot water source to the chiller is from evacuated tube collectors. The cooling water is assumed to enter at $31^{\circ} \mathrm{C}$ (the standard value suggested in the datasheet) and the cooling water outlet is assumed to be used in the domestic hot water circuit or dumped back to the utility tank. The chilled water is then transferred to the house through fan coil setup. The cooling coil draws air from the building and cools it before it blows the air again to the room. The building type is defined as a simple type $12 \mathrm{c}$. The hot water tank stores the energy from the collector and the chilled water is produced whenever cooling is required. The tank has two auxiliary electrical heaters in the top node as an alternative source of energy. A more detailed input, output and parameter definition for each type used is explained below. The time step taken is 3 minutes and the convergence value is 0.01 . The simulation is run for the whole year. The TRNSYS model is shown below in Fig.2. Each of the main components is described in the next chapter below and other than these printers and integrators were used to save the data of the simulation.

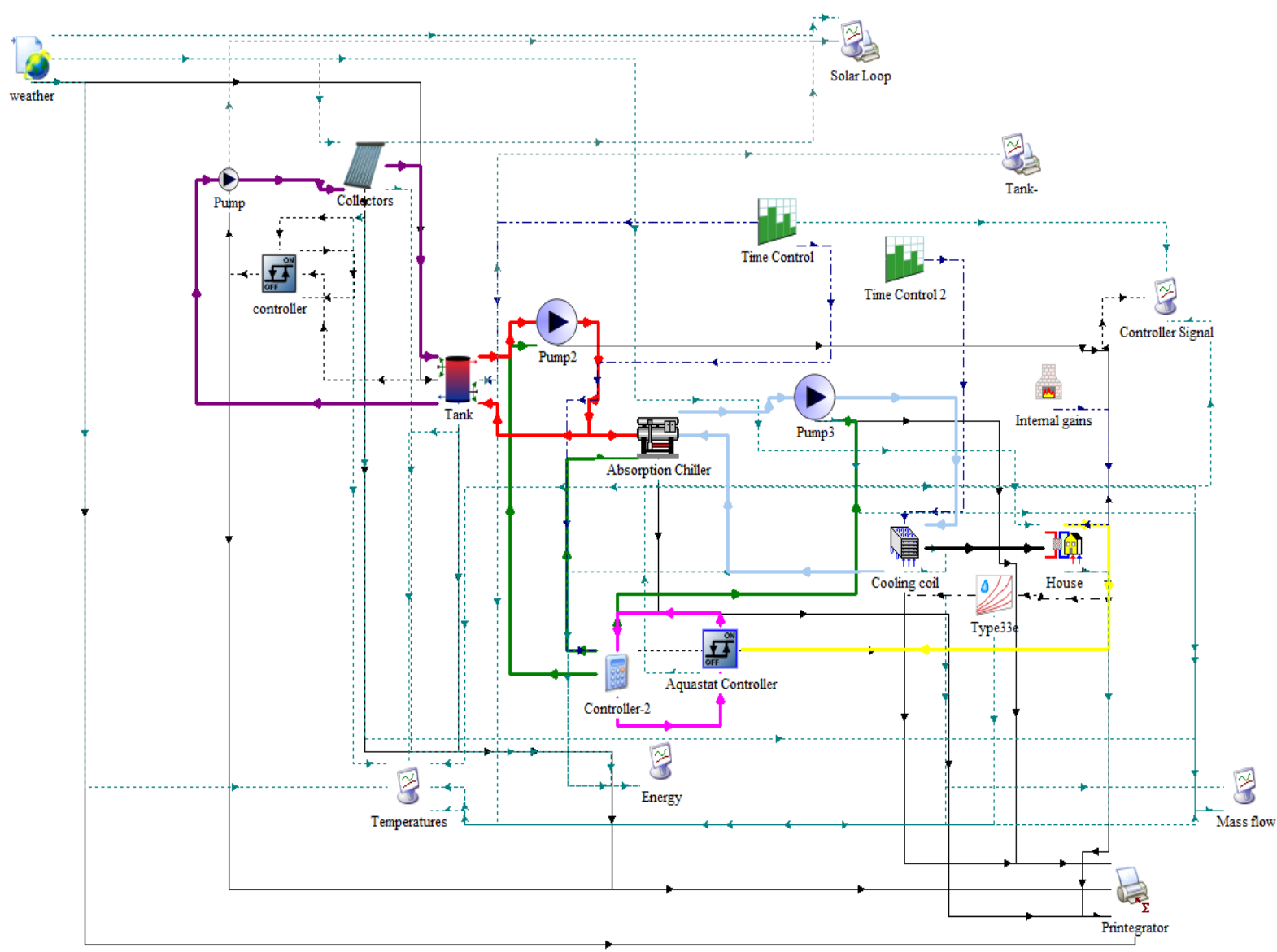

Fig. 2 TRNSYS model of the system 


\section{Components Description}

\subsection{Collectors}

Type 71, Evacuated tube collectors was used. The collector area is one of the parameter studied. The optimum was found to be $220 \mathrm{~m}^{2}$ and 10 collectors were connected in series. All the input was given by the weather data file. The fluid used in the system is just water.

\subsection{Tank}

Type 4c, fixed inlet tank with auxiliary heaters was used. The volume of the tank was also studied. But the optimum was found out to be $20 \mathrm{~m}^{3}$. The tank size were studied in $5 \mathrm{~m}^{3}$ increments and $20 \mathrm{~m}^{3}$ was the sufficient size to have the system operating for the whole day with a considerable amount of solar collectors. The tank was assumed to have 6 nodes with each node $0.25 \mathrm{~m}$ height. The idea of the tank is to keep it mixed at high temperature without high stratifications and hence high flow rate is used. The hot water from the collector is fed into inlet in the top of the tank and the water to the collector is drawn from the bottom of the tank with the pump. The flow is controlled by the on-off controller such that the top of the tank does not exceed $95^{\circ} \mathrm{C}$. The first heater was commanded to turn on when the top node temperature is less than $75^{\circ} \mathrm{C}$ and the second heater will turn on at $70^{\circ} \mathrm{C}$. The power of the heaters are $30 \mathrm{~kW}$ and $10 \mathrm{~kW}$ respectively. The water for the supply to load is as well taken in the top node and returns to the bottom node.

\subsection{Absorption Chiller}

Type 107, single stage Absorption chiller was used. A Yazaki SC 30 model is chosen for this design. The rated power was input as $105 \mathrm{~kW}$ and the COP as 0.8. The example performance characteristics curve for the absorption chiller is edited using the characteristics curve for a medium temperature 75 $95^{\circ} \mathrm{C}$ hot water inlet temperature as mentioned in the data sheet (Yazaki Energy Systems Inc., n.d,). The hot water from the tank is drawn with a pump and the hot water return is feedback to the bottom of the tank. The cooling water is assumed as an open loop and value is input as constant at $31^{\circ} \mathrm{C}$, as mentioned in the standard design point. The outlet of the cooling water can be used in the domestic water usage of the building or a cooling tower will have to be installed which is overlooked in this model. The mass flow for the cooling water is taken as $10.26 \mathrm{~kg} / \mathrm{s}$, the lowest suggest flow in the datasheet. The suggested optimum mass flow rate in the datasheet for hot water and chilled water is 4.8 and $3.05 \mathrm{~kg} / \mathrm{s}$ respectively. The set point temperature of the chiller is set as $7^{\circ} \mathrm{C}$, well within the optimum operating range as suggested in the datasheet. The chiller control signal is received from the controller which compares the aquastat and the time controller and sends the minimum signal of the two (explained in chapter 3.7). The chilled water is pumped to the cooling coil and then is fed back at $12.28^{\circ} \mathrm{C}$ into the chiller.

\subsection{Cooling Coil}

Type 32 cooling coil component, a fan coil setup is used to transfer the cooling energy from water stream to air stream. The incoming chilled water from the pump is transferred in the cooling coil to the air stream which is incoming from the room at $9000 \mathrm{~kg} / \mathrm{hr}$. The flow rate of air is studied. Finally, the total cooling rate is input to the building as incoming cooling rate.

\subsection{Building}

A single zone model, type $12 \mathrm{c}$ was used as a simplification. Then the U value was calculated using external calculators with which the overall loss coefficient was calculated just by multiplying the area to it. And thermal capacitance was calculated manually with the values mentioned previously. The initial room temperature was set as $25^{\circ} \mathrm{C}$, which is the set room temperature. Through a forcing function the internal gains of the building were defined. The average house temperature was input to the aquastat to control the chiller (On-Off).

\subsection{Pumps}

There are totally 3 pumps in the system: one in the solar loop, one for the hot water inlet to the chiller and other for the chilled water delivery to the cooling coil from the chiller. All pumps used are type 3b, variable speed pumps. The mass flow of collector pump and air flow of cooling coil are varied, studied and optimized while other pump flows are fixed.

\subsection{Controllers}

There are two active controllers in the system, one is type $2 \mathrm{~b}$, on-off controller in the collector loop. This is controlled such that the top of the tank is not higher than $95^{\circ} \mathrm{C}$. This controller is an on-off controller which controls the pump of the collector loop by reading the difference between the water inlet from the bottom of the tank and outlet of the collector. If collector outlet is $5^{\circ} \mathrm{C}$ greater than the tank bottom then the pump starts and also the pump shuts down if the top of the tank is above $95^{\circ} \mathrm{C}$.

The other controller is Type 2, Aquastat controller to control the house temperature. The set point temperature is input as $25^{\circ} \mathrm{C}$ and the turn on temperature difference is $0.5^{\circ} \mathrm{C}$ and turn off temperature is zero. The controller controls the chiller 
through an on-off signal with respect to the conditions and the house temperature. In parallel there is a time controller (a type 14h time forcing function) which gives control signal in binary to the chiller and pumps so that they switch on at 8 am and turn off at $8 \mathrm{pm}$. An equation is inserted before the chiller which compares both the aquastat and the time controller and gives an out coming signal as minimum signal of the two i.e. even if the room temperature is above $25^{\circ} \mathrm{C}$ at the night the chiller doesn't turn on. Also, there is a similar $14 \mathrm{~h}$ type forcing function connected to the cooling coil which controls the air loop.

\subsection{Internal Gains}

The internal gains are input with a type 14c, forcing function. The building is assumed to be occupied by 100 persons working with a computer each from 9 a.m. to 8 p.m during working days.

\section{Parametric study}

One of the aims of the project is to find optimum parameters for the assumed system. The study of the parameters starts with the collector size. The collector size, tank size and mass flow depend on the required amount of hot water for the absorption chiller. The collector size decides the time required to fill the tank with the hottest water and with less sunshine hours. On the other hand, the tank decides the amount of hottest water in the tank available for use during the sunset hours. The mass flow decides the temperature of the hottest part of the tank and since the chiller already mixes the tank with it high flow, we can also maintain a high flow here in this loop also so as to have a low temperature difference between the inlet and outlet of the collector with a small tank. More or less if the collector size is increased, up to an extent, the tank size can be reduced. In this case we have a roof top of $289 \mathrm{~m}^{2}$ and so we can utilize this area. There is always a tradeoff between the tank size, collector area and the load requirement. The system can run with a $60 \mathrm{~m}^{2}$ collector area but the volume of the tank required is huge and hence in the efforts of reducing the tank size and at the same time not letting the top of the tank fall lower than $75^{\circ} \mathrm{C}$ often, the collector size was increased to $220 \mathrm{~m}^{2}$. It is better not to increase the collector area more than this since the storage tank and free movable space have to be accounted in the roof space. Also, the single stage $\mathrm{LiBr}$ low temperature absorption system was chosen because of the inability of the roof space to give higher temperatures. If the collector area is reduced to 150 $\mathrm{m}^{2}$ then most of the time the top of tank is at $75^{\circ} \mathrm{C}$ and the auxiliary has to be used often, to counter act this the tank size has to be doubled which makes no sense. And also, the flow rate for such an area was set as $12000 \mathrm{~kg} / \mathrm{hr}$, which is a high flow loop and as we increase this the tank is mixed well and the difference between the top and bottom decreases and the auxiliary energy use is reduced. But in the long run, more energy will be spent than the saved energy from the auxiliary due to the higher pump energy consumption and pump size at higher flowrate in the loop.

Then the amount of water drawn from the tank also plays an important role in the size of the tank, since the usage of the tank is important only during the sunset hours, the tank can be as small as $20 \mathrm{~m}^{3}$ and as the storage size is increased, the system gets stable but the price of huge storage tanks are also increasing and the space is also a constraint. The collector efficiency also rises if we increase the tank size. If the system is to be run for the whole day, also in the night then the storage tank size can be increased.

Only with the change of tank size, the system will be sufficient to run the whole day ( 24 hours), as the collectors and chiller is designed high enough to satisfy this need. The $70 \mathrm{~kW}$ chiller could have been used but they can't provide $7^{\circ} \mathrm{C}$ chilled water temperature when the hot water inlet grade or temperature is a bit lower than $80^{\circ} \mathrm{C}$ during a high summer day when the cooling demand is huge. Hence the next big chiller, an $110 \mathrm{~kW}$ chiller has to be used. This also carries an advantage as mentioned earlier that this chiller can work even in a 24-hour working system with just an additional storage tank. At last the coil air mass flow had to be studied.

Since the air flow is directly related to the temperature of air delivered out the coil and the temperature of the fluid back to the chiller, if the mass flow is increased, the temperature of the air out of coil is decreased, decreasing the change in temperature of the fluid in the cooling coil and vice versa. The air mass flow was set such that there is about $5^{\circ} \mathrm{C}$ difference in the fluid in the cooling coil. In Fig. 3, the study of the flow rate of the collector and cooling air is shown. It can be seen that the collector flow rate has a proportional increase in the annual solar energy gain but after $8000 \mathrm{~kg} / \mathrm{h}$ it does not have that much gain and in other case the pump will consume more power and the tank will be mixed.

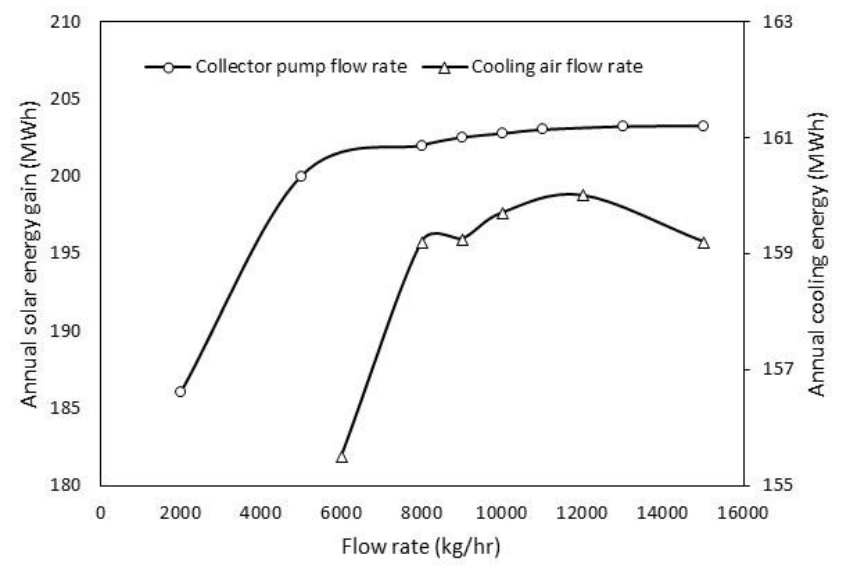

Fig. 3 Parametric optimization of collector pump flow rate and cooling air flow rate 
And for cooling air, the case is completely different, after $12000 \mathrm{~kg} / \mathrm{hr}$, the cooling energy delivered reduces and does not also have an increase in energy delivered with increase in mass flow.

In Fig.4, the sensitivity analysis of the collector area and tank volume is studied for their effect in solar fraction, $\mathrm{COP}_{\text {solar, }}$ collector efficiency and auxiliary use. The collector area has a lot of effect on the system solar fraction in comparison to the tank. This can be seen in the analysis when increasing the tank size with a $220 \mathrm{~m}^{2}$ collector area has very little effect on the solar fraction but when changing the collector area, the case is different. Collector efficiency and auxiliary use is lower and higher with when the tank volume is made constant and the collector area is reduced but the vice versa does not shows a different value. Acting differently is the $\mathrm{COP}_{\text {solar, it is not }}$ affected that much by changing the collector area, but the tank size plays an important role.

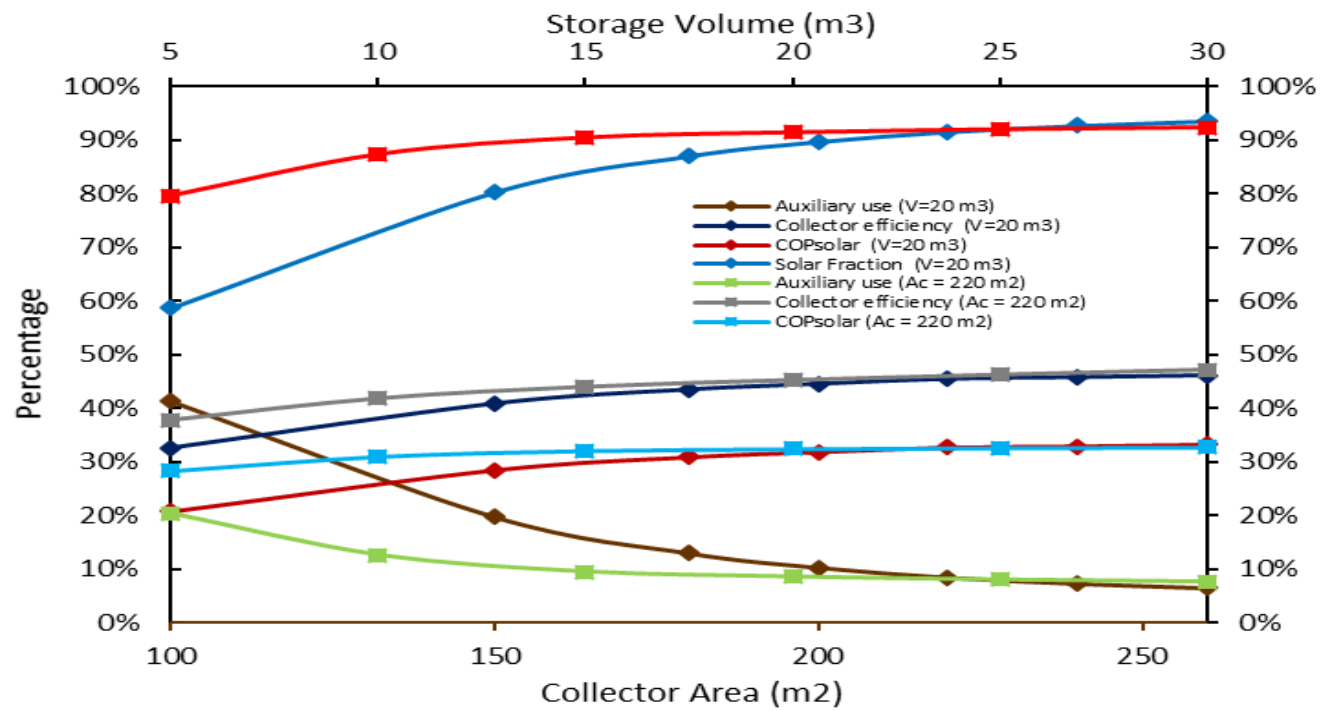

Fig. 4 Parametric study results showing various values over different storage volume and collector area

\section{Results}

The simulation results are shown in Fig.5 and Fig.6. The simulation results are graphed for the whole year, tank_out (red) shows the temperature of the hot water taken out of the tank in Fig.5. The tank remains between 80 and $95^{\circ} \mathrm{C}$ and the electrical heater heats up the tank if it reduces less than $80^{\circ} \mathrm{C}$ due to increased demand or reduced solar energy. This can be seen in Fig. 6 where tank top node temperature, bottom node temperature and auxiliary heating element power is shown. The use of two auxiliary heating step is also seen. The mean room temperature T_room (black) shows that the rooms is controlled at the set point temperature irrespective of the T_amb, ambient temperature. The cold energy exchange between chilled liquid and air is also seen in the Fig.5.

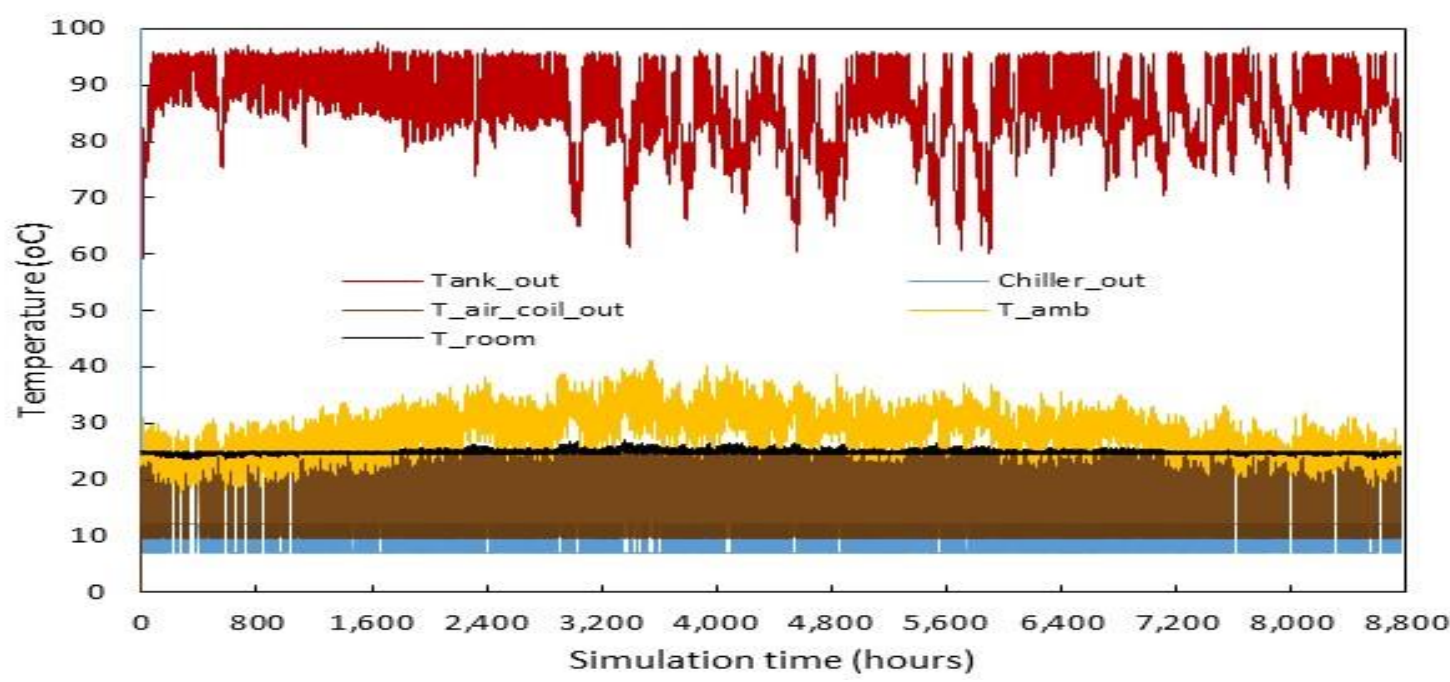

Fig. 5 Simulation results of the system showing storage outlet (Tank_out), chilled water from absorption chiller (chiller_out), air from the coil (T_air_coil_out), ambient temperature (T_amb), Mean room temperature (T_room) over the year (Simulation Time) 


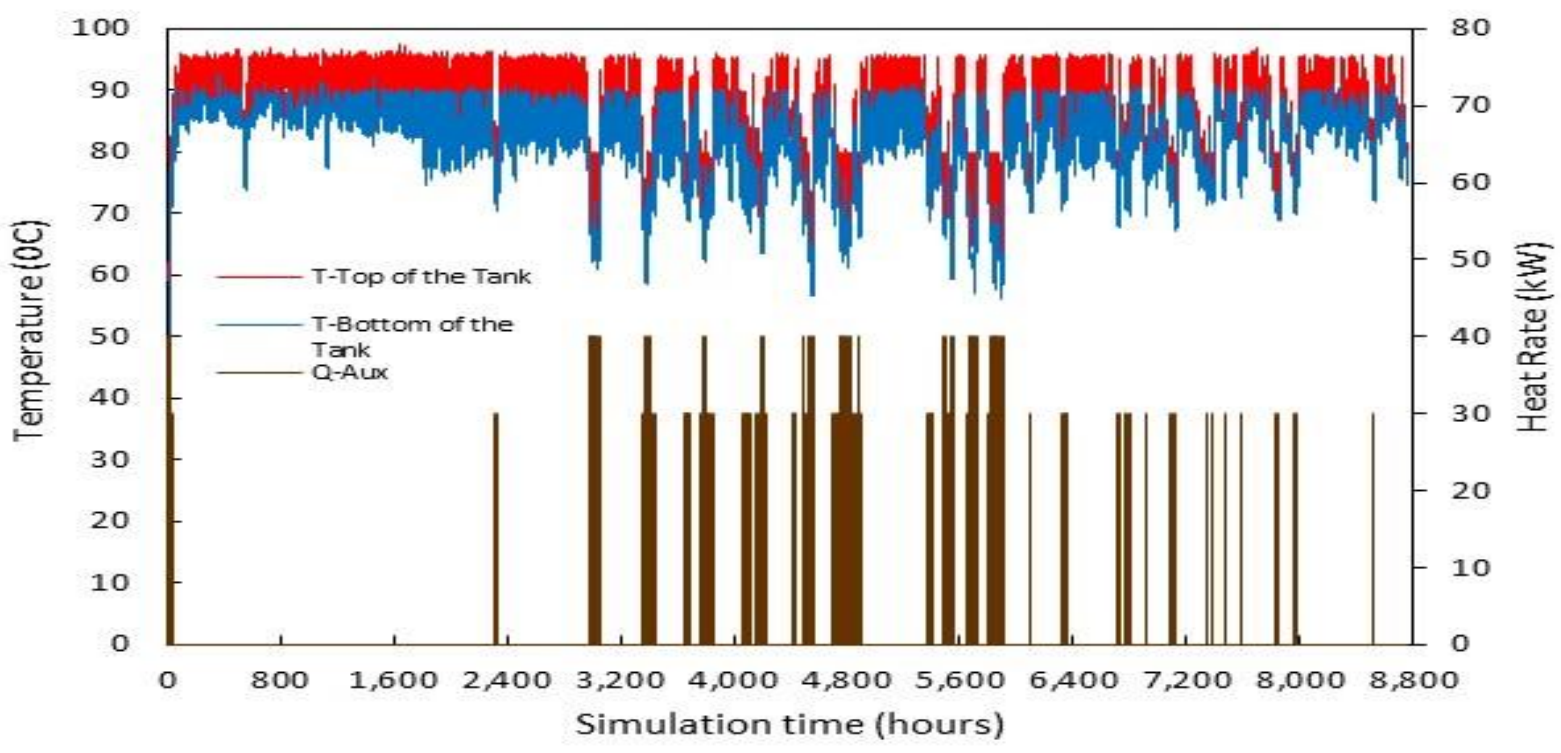

Fig. 6 Simulation results showing top and bottom temperature of the tank and Auxiliary heat rate over the simulation time.

Since the electrical power of the pumps could not be estimated exactly, the values of total electrical energy required and electrical COP is not calculated. And as shown in Table 1, auxiliary heater energy usage, collector efficiency, COPsolar is calculated. The auxiliary heater is used at $8.54 \%$ of the times the chiller was used. This value decreased with increase in collector area, tank size and a little with the mass flow. Also, the collector efficiency is increased with these factors, especially when the tank size was increased as it can be noticed when the tank is big it will take some time to get the top node to $95^{\circ} \mathrm{C}$ and hence it will operate more during sunshine hours increasing the heat energy from the source. The COP solar at 0.35 in a year seems to be good, since the solar gains in India is high this value is meant to be correct with some uncertainties.

In Fig.7, the monthly values of the solar energy used, auxiliary energy used, solar fraction, cooling energy and COP is shown. It can be seen that auxiliary energy is used in summer to satisfy the peak cooling demand and this is the reason for the reduced solar fraction in the winter. In contrary $\mathrm{COP}_{\text {solar }}$ is higher in summer.

Table 1

Formulas for the key parameters and their values

\begin{tabular}{|c|c|c|}
\hline $\begin{array}{l}\text { Use of } \\
\text { auxiliary } \\
\text { heater }\end{array}$ & $\begin{array}{c}\text { Auxiliary heater energy } \\
\text { consumption/Total cooling energy } \\
\text { delivered }\end{array}$ & $8.42 \%$ \\
\hline $\begin{array}{l}\text { Collector } \\
\text { efficiency }\end{array}$ & $\begin{array}{c}\text { Total energy from the collector/Total } \\
\text { insolation on the area of the collector } \\
\text { surface }\end{array}$ & $45.38 \%$ \\
\hline COPsolar & $\begin{array}{l}\text { Total cooling energy - Auxiliary } \\
\text { energy/ Total insolation on the area of } \\
\text { surface }\end{array}$ & 0.35 \\
\hline COPchiller & $\begin{array}{l}\text { Total hot water energy utilized/Total } \\
\text { chilled water energy delivered }\end{array}$ & 0.78 \\
\hline
\end{tabular}

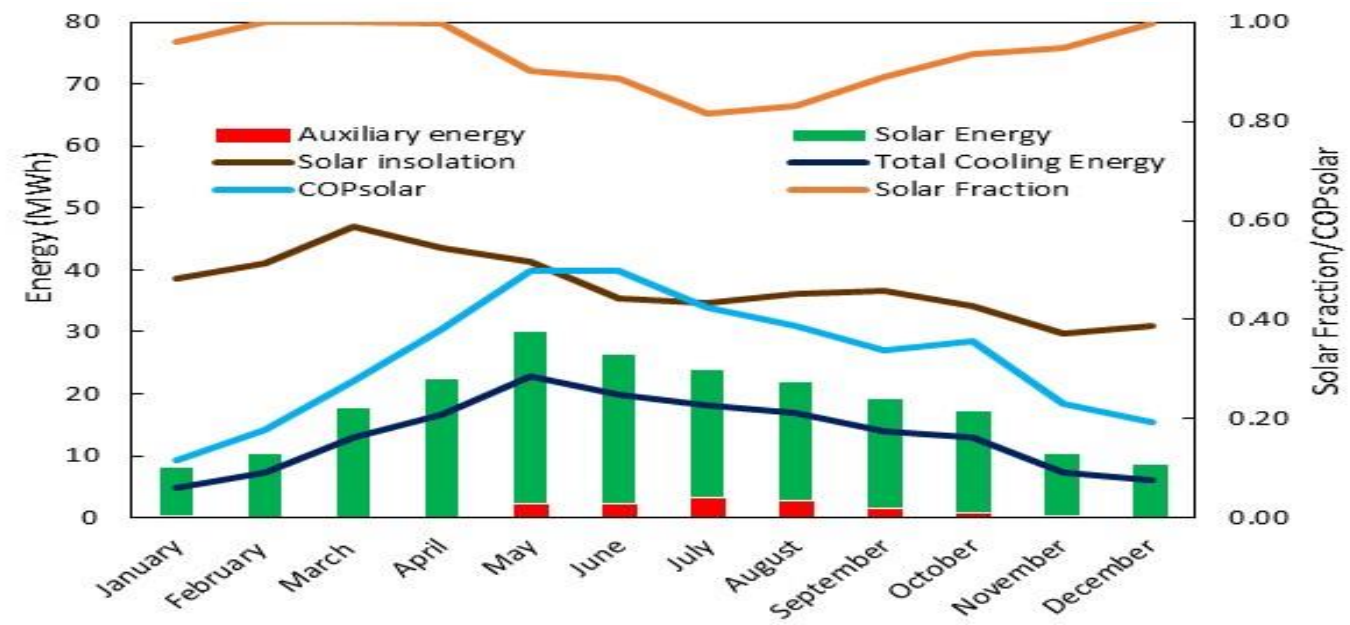

Fig. 7 Simulation results of monthly energy production values and system efficiency 


\section{Economic Evaluation}
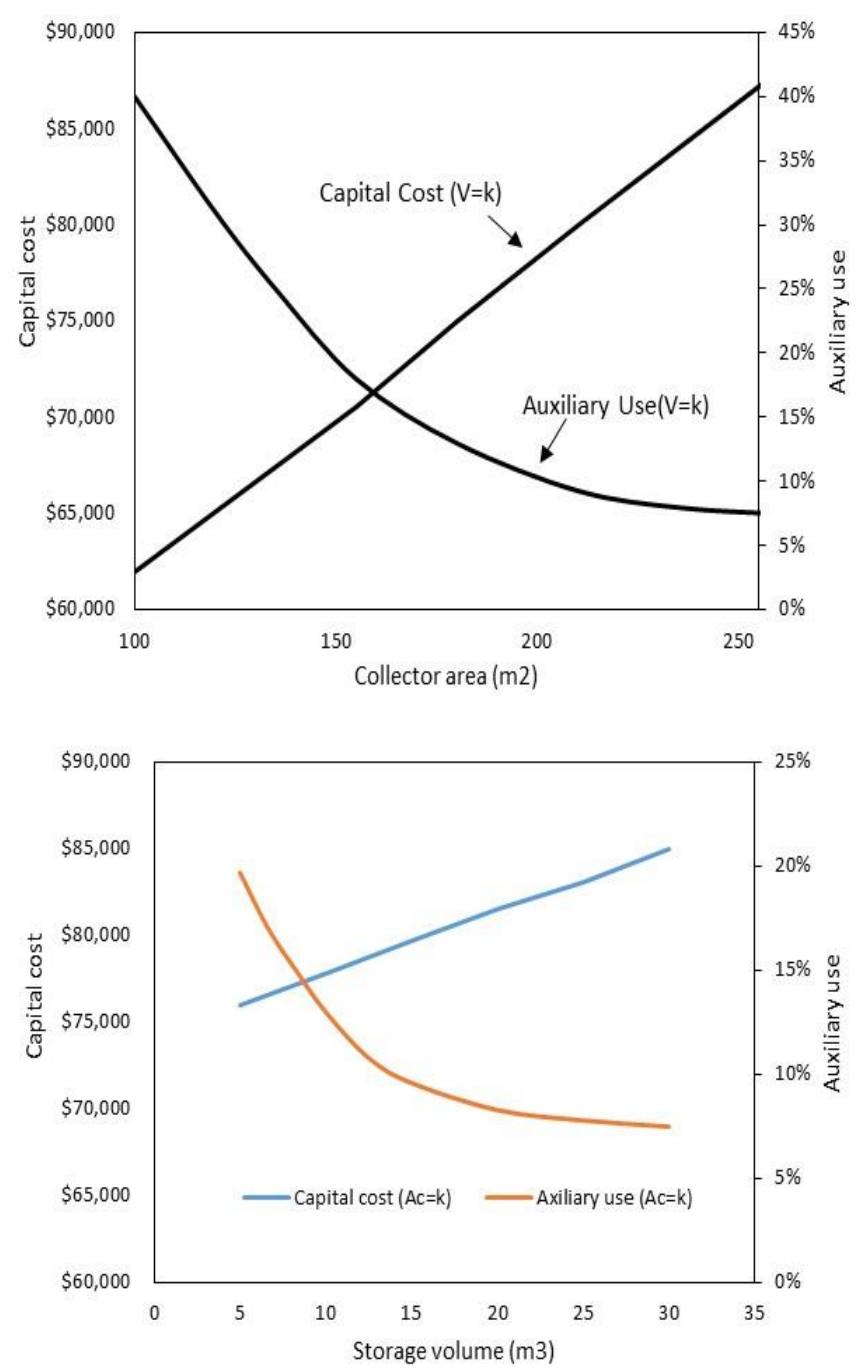

Fig. 8 Changes in capital cost and auxiliary energy use in varying collector area and storage volume

The economic calculations are done with the quotations from the component sellers and then the service costs as estimated as per the situation in India. Sunmaxx Solar was the enquired company for the solar collectors and mounting. According to them a wholesale price of $\$ 750$ per VH30 collector (Sunmaxx Solar Inc.,n.d.,). As per the collector area and collector field, 42 collectors will be required in this case. The wholesale rate of cubical storage tanks with less insulation is priced as $\$ 300 / \mathrm{m}^{2}$ and the absorption chiller is taken as $\$ 300 / \mathrm{kW}$. The pumps and cooling coil is taken as $\$ 2000$ and the only replacement cost during the 25 years lifetime will be the cooling coil with 12 years lifespan. $10 \%$ of component subtotal were assumed for piping, valves, controllers and delivery ducts while 5\% was taken for installation costs as listed in Table 2.

With these values the total capital investment for the absorption cooling is estimated as $\$ 81,650$. Then the maintenance cost is assumed as $2 \%$ of capital cost every year. Since it is know that $12 \mathrm{MWh}$ of electrical energy is estimated to be consumed by electric heater, the total electricity consumption in a year is estimated to be $15 \mathrm{MWh}$ with $3 \mathrm{MWh}$ dedicated to the efficient pumps, absorption chiller and controllers.

For the payback comparison, the costs of the traditional air conditioners were also estimated. The efficient Hitachi air conditioners (16 units) will cost $\$ 12,846$ and the maintenance is assumed to be $500 \$$ year and the electricity bill for such a system is calculated as \$ 6509/year for 51665kWh electricity consumption. The electricity inflation rate is assumed as $4 \%$ and maintenance inflation rate as $5 \%$. As shown in Table 3, the traditional air conditioner unit for this building is estimated as $\$ 12,846$. In addition, comes the maintenance and electric costs as mentioned.

Table 2

Assumed expenses for solar absorption cooling system

\begin{tabular}{|c|c|c|c|c|}
\hline Component & Description & $\begin{array}{l}\text { Unit } \\
\text { price }\end{array}$ & $\begin{array}{l}\text { Life } \\
\text { span }\end{array}$ & $\begin{array}{c}\text { Total } \\
\text { cost }\end{array}$ \\
\hline $\begin{array}{l}\text { Collectors \& } \\
\text { Mounting }\end{array}$ & $\begin{array}{l}\text { Evacuated } \\
\text { tube } \\
\text { collectors (42 } \\
\text { No.) }\end{array}$ & $\$ 750$ & $\begin{array}{c}25 \\
\text { years }\end{array}$ & $\$ 31,500$ \\
\hline Storage tank & $\begin{array}{l}\text { Hot water } \\
\text { storage } 20 \\
\mathrm{~m}^{3}\end{array}$ & $\begin{array}{c}\$ \\
300 / \mathrm{m}^{3}\end{array}$ & $\begin{array}{c}20 \\
\text { years }\end{array}$ & $\$ 6,000$ \\
\hline $\begin{array}{l}\text { Absorption } \\
\text { Chiller }\end{array}$ & $\begin{array}{l}30 \text { ton } \\
(105 \mathrm{~kW}) \\
\text { single effect } \\
\text { absorption } \\
\text { chiller }\end{array}$ & $\begin{array}{c}\$ \\
300 / \mathrm{kW}\end{array}$ & $\begin{array}{c}20 \\
\text { years }\end{array}$ & $\$ 31,500$ \\
\hline \multicolumn{4}{|c|}{ Pumps and cooling coil } & $\$ 2,000$ \\
\hline \multicolumn{4}{|c|}{ Subtotal } & $\$ 71,000$ \\
\hline $\begin{array}{l}\text { Piping, } \\
\text { valves, } \\
\text { control } \\
\text { system and } \\
\text { delivery } \\
\text { ducts }\end{array}$ & \multicolumn{3}{|c|}{$\begin{array}{l}10 \% \text { of the components } \\
\text { subtotal }\end{array}$} & $\$ 7,100$ \\
\hline $\begin{array}{l}\text { Labour costs } \\
\text { for } \\
\text { Installation }\end{array}$ & \multicolumn{3}{|c|}{$5 \%$ of the components subtotal } & $\$ 3,550$ \\
\hline \multicolumn{4}{|c|}{$\begin{array}{c}\text { Solar energy system capital investment } \\
\text { cost }\end{array}$} & $\$ 81,650$ \\
\hline $\begin{array}{l}\text { Maintenance } \\
\text { cost per year }\end{array}$ & \multicolumn{3}{|c|}{$2 \%$ of the capital investment } & $\begin{array}{c}\$ \\
1,633 / \text { year }\end{array}$ \\
\hline $\begin{array}{l}\text { Electricity } \\
\text { consumption } \\
\text { costs }\end{array}$ & \multicolumn{3}{|c|}{$\begin{array}{l}15000 \mathrm{kWh} / \text { year* Current Unit } \\
\text { electricity price }(0.126 \$ / \mathrm{kWh})\end{array}$} & $\begin{array}{c}\$ \\
1,890 / \text { year }\end{array}$ \\
\hline
\end{tabular}


Table 3

Expenses for traditional compression air conditioning

\begin{tabular}{lcc}
\multicolumn{1}{c}{ Component } & Expense \\
\hline Air Conditioner unit & & $\$ 12,846$ \\
Air conditioner maintenance & & $\$ 500 /$ year \\
$\begin{array}{l}\text { Yearly electricity bill (51,665 } \\
\text { /year* Current unit electricity }\end{array}$ & $\$ 6,509 /$ price \\
$(0.126 \$ / \mathrm{kWh}))$ & & \\
\hline
\end{tabular}

. With these values the simple payback of installing a solar absorption cooling instead of traditional unit will be 13.6 years and it would take 15.5 years for the solar absorption cooling system to pay its full capital investment back. This calculation also takes into account the capital subsidy being offered by the government. This subsidy is the lower value of $30 \%$ capital investment or 48.17 \$/sq.m collector area (TEDA,n.d)(HAREDA,n.d.). For this calculation it is $48.17 \$ / \mathrm{sq} . \mathrm{m}$ and this is $\$ 10,597$. At some special cases the government might increase the subsidy to $60 \%$ if the system is a new technological approach and the chances of getting this increased subsidy is high for this system but this is overlooked for this calculation. Also soft loans are available for 5\%p.a. (TEDA,n.d.)(HAREDA,n.d.) but since it is a commercial building it is assumed that the owner itself can invest in the system. For such owners there are tax exemption for 10 years for their investment money and an accelerated depreciation of $80 \%$ is also allowed by the government (Make in India, n.d.). These are also not taken into account in this economic evaluation.

\section{Conclusion}

From the results, it could be said solar electric cooling in India is economically possible but still it is high investment. But it should be rather easy for the large company owners to install it in their office buildings. Even for schools, colleges, libraries, offices and other public and government buildings can save some money and at the same time increase the brand value of the organisation with the green tag. These systems also are a kind of marketing for them. It is recommended to install the systems as soon as possible when the government has subsidies and other incentives. For now, the government wants to install more of solar energy according to their mission and policies (JNNSM,2008). Always it is not the best case to have an efficient system and at some point, there is a trade-off between efficiency and cost. The parameters were selected with this in mind after the study. Also, it is to be noted that the electricity price inflation is underestimated in this calculation and the expectation in the global level is higher. In terms of efficiency, the cities in India have a lot of solar irradiation all through the year and for the current system the COPsolar is 0.35 which is well higher than most of the systems of this kind.

This research also provides some expectations to policy makers. Until now the solar energy mission is India is bounded only for large systems, but the success behind any solar market is small system owners which directly benefits the citizens and making them to invest a small amount each and take part in the mission. For this the government should give a push through incentives and policies.

\section{Acknowledgments}

I am hereby obliged to thank Prof. Dr. Chris Bales for his advice and supervision of this project. Special thanks for ESES, Dalarna University, Sweden for kick starting my solar energy engineering career. If not for the support of my family and friends, I am not in such a position I am, thanks.

\section{References}

Al-Alili, A., Islam, M.D., Kubo, I., Hwang, Y., Radermacher, R., (2012). Modeling of a solar powered absorption cycle for Abu Dhabi. Applied Energy 93, 160-167. doi:10.1016/j.apenergy.2010.11.034

Breyer, C., (2014). An update on Grid Parity, 29th EUPVSECSelf-consumption business models - technical and economic challenges, Netherlands.

Budania, A., Ahmad, S., Jain, S., (2013). Transient simulation of a solar absorption cooling system. International Journal of Low-Carbon Technologies. doi:10.1093/ijlct/ctt060

Calise, F., (2010). Thermoeconomic analysis and optimization of high efficiency solar heating and cooling systems for different Italian school buildings and climates. Energy and Buildings 42, 992-1003. doi:10.1016/j.enbuild.2010.01.011

Dickinson, J.K., Hess, R.O., Seaton, J., van Lambalgen, H., Burnham, A.L., (2010). Cost and performance analysis of a solar thermal cooling project, in: ASME 2010 4th International Conference on Energy Sustainability. American Society of Mechanical Engineers, pp. 217-223.

Eicker, U., Colmenar-Santos, A., Teran, L., Cotrado, M., BorgeDiez, D., (2014). Economic evaluation of solar thermal and photovoltaic cooling systems through simulation in different climatic conditions: An analysis in three different cities in Europe. Energy and Buildings 70, 207223. doi:10.1016/j.enbuild.2013.11.061

Eicker, U., Pietruschka, D., (2009). Design and performance of solar powered absorption cooling systems in office buildings. Energy and Buildings 41, 81-91. doi:10.1016/j.enbuild.2008.07.015

Florides, G.A., Kalogirou, S.A., Tassou, S.A., Wrobel, L.C., (2002). Modelling and simulation of an absorption solar cooling system for Cyprus. Solar Energy 72, 43-51.

Fong, K.F., Chow, T.T., Lee, C.K., Lin, Z., Chan, L.S., (2010). Comparative study of different solar cooling systems for buildings in subtropical city. Solar Energy 84, 227-244. doi:10.1016/j.solener.2009.11.002

Ghafoor, A., Munir, A., (2015). Worldwide overview of solar thermal cooling technologies. Renewable and Sustainable Energy Reviews 43, 763-774. doi:10.1016/j.rser.2014.11.073

Ghafoor, A., Munir, A., (2014). Thermo-economic Optimization of Solar Assisted Heating and Cooling (SAHC) System. 
Citation: Narayanan, M. (2017).Techno-Economic Analysis of Solar Absorption Cooling for Commercial Buildings in India. Int. Journal of Renewable Energy Development, 6(3), 253-262, doi.org/10.14710/ijred.6.3.253-262

$\mathrm{P}$ a g e | 262

International Journal of Renewable Energy Development (IJRED) 3. doi:10.14710/ijred.3.3.217-227

HAREDA - Department of Renewable Energy Government of Haryana [WWW Document], n.d. URL http://hareda.gov.in/index.php?model=gallery\&nid=21 (accessed 11.30.16).

India Today, (2015) (Dated-28.07.2015), Infosys to set up 7MW solar plant at Hyderabad campus. URLhttp://indiatoday.intoday.in/technology/story/infosys-toset-up-7mw-solar-plant-at-hyderabadcampus/1/454565.html (accessed 9.20.15).

JNNSM (Jawaharlal Nehru National Solar Mission), MNRE (Ministry of Renewable Energy) Indian Government, 30.06.2008, URL http://www.mnre.gov.in/solarmission/jnnsm/mission-document-3/

Kohlenbach, P., (2006). Solar cooling with absorption chillers: Control strategies and transient chiller performance. Dissertation, TU Berlin.

Lazzarin, R.M., (2014). Solar cooling: PV or thermal? A thermodynamic and economical analysis. International Journal of Refrigeration 39, 38-47. doi:10.1016/j.ijrefrig.2013.05.012

Make in India(Renewable Energy) [WWW Document], n.d. URL http://www.makeinindia.com/sector/renewable-energy (accessed 11.30.16).

Mittal, V., Kasana, K.S., Thakur, N.S., (2013). Performance evaluation of solar absorption cooling system of Bahal (Haryana). Journal of the Indian Institute of Science 85, 295.

Mittal, V., Kasana, K.S., Thakur, N.S., (2006). Modelling and simulation of a solar absorption cooling system for India. Journal of Energy in Southern Africa 17, 65-70.
Narayanan,M., (2015). Techno-Economic Analysis of Solar Photovoltaic Cooling in India. International Journal of Emerging Technology and Advanced Engineering Volume 5, Issue 5,286-290

Otanicar, T., Taylor, R.A., Phelan, P.E., (2012). Prospects for solar cooling - An economic and environmental assessment. Solar Energy 86, 1287-1299. doi:10.1016/j.solener.2012.01.020

Pietruschka, D., Jakob, U., Eicker, U., (2010). Solar cooling for southern climates, double effect absorption chillers with high concentrating collectors versus standard single effect systems, in: Proceedings of the Eurosun 2010 Conference, Graz, Austria.

Sunmaxx Solar Inc., n.d., Product Datasheet-Thermopower VHP Vacuum Tube Collectors, NY, USA

TEDA (Tamilnadu Energy Development Agency)- Solar Water Heating Systems TEDA, n.d. URL http://teda.in/solarwater-heating-systems/ (accessed 11.30.2016)

The World Bank, (2008), Residential Consumption of Electricity in India, India: Strategies for Low Carbon Growth

TNERC, (2012), Tamil Nadu Solar Energy Policy 2012, Tamilnadu Electricity Commission, Government of India.

Transient System Simulation Tool - TRNSYS [Software], 2014, Version 17, . Thermal Energy System Specialists, LLC., Madison USA.

TRNSYS Manual, Transient System Simulation Tool - TRNSYS, (2014), Version 17, . Thermal Energy System Specialists, LLC., Madison USA.

Yazaki air conditioners - YFC-S series datasheet, n.d. . Yazaki Energy Systems Incorporated, Texas, USA. 